\title{
Working
}

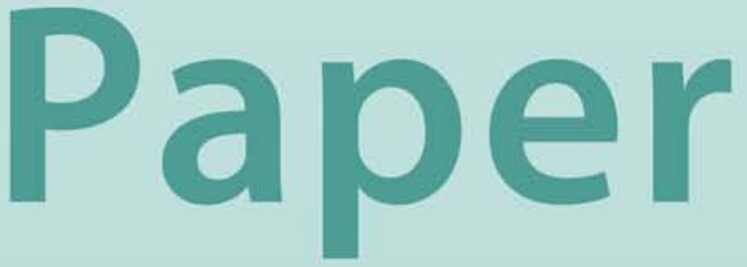




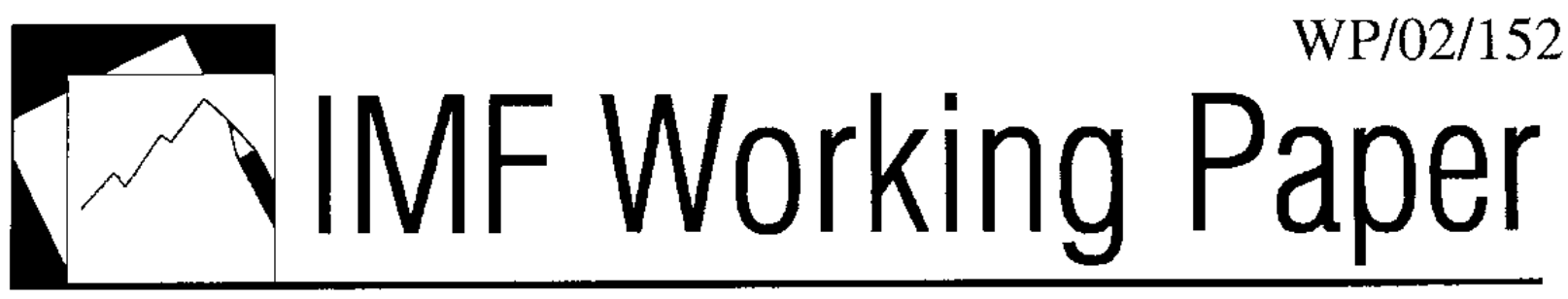

Corporate Performance and Governance in Malaysia

Yougesh Khatri, Luc Leruth, and

Jenifer Piesse 


\title{
IMF Working Paper
}

Asia and Pacific Department

\section{Corporate Performance and Governance in Malaysia}

\author{
Prepared by Yougesh Khatri, Luc Leruth, and Jenifer Piesse ${ }^{1}$ \\ Authorized for distribution by E. Ahmad and K. Kochhar
}

September 2002

\begin{abstract}
The views expressed in this Working Paper are those of the author(s) and do not necessarily represent those of the IMF or IMF policy. Working Papers describe research in progress by the author(s) and are published to elicit comments and to further debate.
\end{abstract}

This paper measures corporate sector performance (efficiency) and empirically examines the role of corporate governance. A stochastic frontier with inefficiency effects is fitted to a panel dataset of 31 of the largest nonfinancial companies listed on the Kuala Lumpur Stock Exchange for the pcriod 1995 to 1999 . Focusing specifically on the impact of the system of corporate governance and the level of control on firm-level performance, results show an underlying vulnerability in these firms, exacerbated by their reliance on bank-based borrowing and a highly concentrated shareholding structure with complex cross holdings. Furthermore, debt does not appear to have the control features present in outsider systems of corporate governance.

\section{JEL Classification Numbers:O47, P210}

Keywords: corporate governance, stochastic frontier, Southeast Asian crisis

Authors’E-Mail Addresses: jenifer.piesse@kcl.ac.uk; ykhatri@imf.org; lleruth@imf.org

1 Yougesh Khatri and Luc Leruth are respectively in the Asia-Pacific Department and the Fiscal Affairs Department of the International Monetary Fund; Jenifer Piesse (to whom correspondence relating to this paper should be sent) is in the School of Social Science and Public Policy, Kings College, University of London, UK and the University of Stellenbosch, RSA. The authors would like to thank, without implication, Constantijn Claessens, Yves Crama and seminar participants in Kings College London and the Asia-Pacific department of the IMF for their helpful comments, and the Kuala Lumpur Stock Exchange for their help in providing the data. 


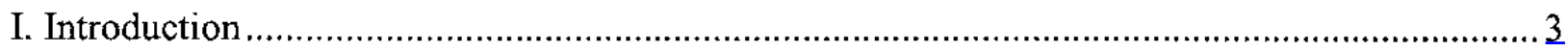

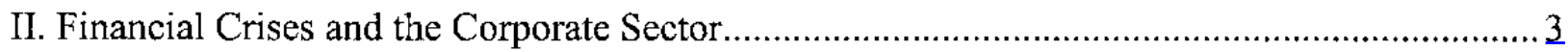

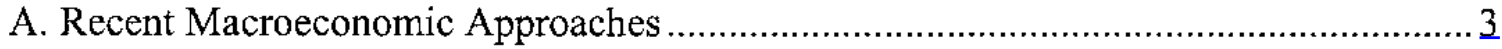

B. Microeconomic and Institutional Approaches..................................................... 4

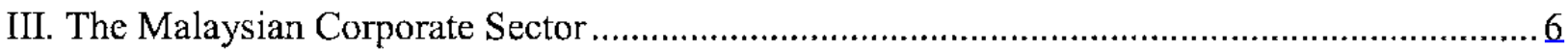

IV. Corporate Performance Measurement...................................................................

V. Measuring Firm-level Efficiency using Stochastic Frontiers with Inefficiency Effects ........... 9

VI. Models, Estimation, and Hypothesis Tests ............................................................. 11

A. Estimation and Tests..................................................................................... 12

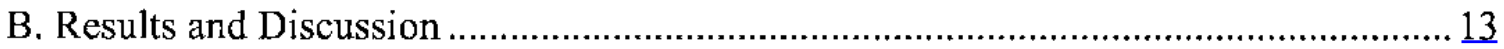

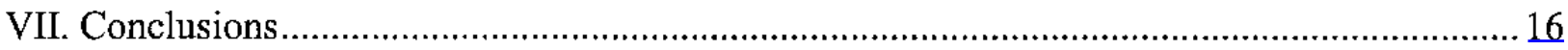

Tables

1. Summary Data Statistics and Correlation Coefficients ............................................. 17

2. Trends in Variables: Annual Means and Standard Deviations....................................... 18

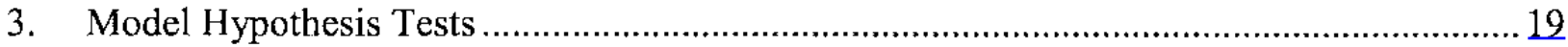

4. Maximum-Likelihood Estimates (t-statistics) ..................................................20

5. Firm-Level Efficiency Levels: Annual Means and Panel ............................................2

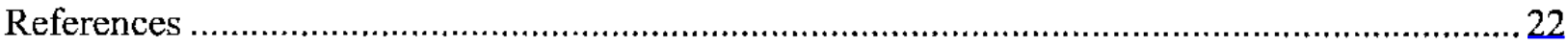




\section{INTRODUCTION}

Corporate sector vulnerabilities and poor governance have frequently been identified as important contributors to the Asian crisis and, in some recent theoretical and empirical work, sometimes seen as its main cause. While the debate on the origins of the crisis will no doubt continue, and whether poor governance was a main cause or simply a contributory factor, it is clearly important to be able to identify the major weaknesses in corporate governance and ensure that sufficient reforms are undertaken to develop a robust system of governance that will help the corporatc sector cope with future financial crisis.

This paper uses a stochastic frontier model with inefficicncy effects on a sample of the largest firms on the Kuala Lumpur Stock Exchange (KLSE), to determine the major components of firm failure during this period, including the influence of the existing governance structure. There are a number of alternative hypotheses relating the corporate sector to the crisis, including: the explanation of poor corporate performance in response to external shocks such as falls in aggregate demand and increases in interest rates; the view that corporate performance began to decline before the onset of the crisis and thus left firms vulnerable; and recent theoretical models by Krugman (1999), and Schneider and Tornell (2001), that explicitly model the role of corporate balance sheets in the crisis. Note, however, that these papers do not explicitly take into account the governance structure, nor do they attempt to measure inefficiency. In this paper, we focus on corporate governance, in particular on the level of control of large shareholders.

The paper begins with a brief discussion in Section II of the literature on financial crises that includes the role of corporate fundamentals and governance structures. Section III provides an overview of the Malaysian corporate sector, and Section IV describes the measurement of corporate sector performance, with some comments on the overall economy and a description of the data used in this study. The model is laid out in Section V. Section VI describes the estimations and hypotheses tests, and also discusses the results (and some implications of the system of governance in place in Malaysia). Conclusions are presented in Section VII.

\section{Financial Crises and the Corporate Sector}

The main literature on crises has been at the macroeconomic level, focusing on macroeconomic fundamentals (first-generation models) or self-fulfilling crises modelled on bank runs (secondgeneration models), and has only recently (in models such as Krugman, 1999 or Schneider and Tornell, 2001) explicitly included the corporate sector as a central element. Another branch of literature, more directly relevant to this paper, is microeconomic-based, examining either firm level data to investigate the role of the corporate sector in the crisis or focusing on the role of institutional factors and corporate governance. This section briefly reviews these approaches in the context of the Asian crisis (for a fuller review, see Khatri, 2001 and the references therein).

\section{A. Recent Macroeconomic Approaches}

The Asian crisis seemed to move the consensus toward the second-generation models as more representative of more recent crises. However, this view is not unanimous and a number of major

positions have emerged in the post-crisis literature. One is that of Corsetti and others (1998), who 
suggest that the apparent soundness of macroeconomic policy was misleading, since implicit government guarantees to banks and the corporate sector led to moral hazard lending and the build-up of a hidden government deficit. Thus, the apparent soundness of the macroeconomic policy was an illusion. Another view, associated with Radelet and Sachs (1998), is that there was not a major problem with the policies pursued by crisis countries (and that investments were basically sound), but they suffered from financial fragility, which made them vulnerable to selffulfilling pessimism on the part of international lenders (see Chang and Velasco, 1998).

More recently, Krugman (1999) suggested that for the major crises in the Asian countries, neither the first- nor the second-generation crisis models have much relevance. By conventional measures, the fiscal positions were strong and there were no clear trade-offs between employment and exchange rate stability (such as existed in the United Kingdom in 1992). While still essentially a macroeconomic approach, Krugman emphasizes other factors omitted from previous models-namely, the role of corporate balance sheets in determining firms' ability to invest and the role of capital flows in affecting real exchange rates. Krugman also questions the moral hazard argument (central to Corsetti and others, 1998), claiming that there is ample evidence of significant investment in the Asian countries prior to the crisis, including indirect foreign purchases of equity and real estate, which was clearly not protected by any form of implicit guarantee. In sum, the three key elements in Krugman's model arc: (i) contagion; (ii) the transfer problem, or the need to effect a huge change in the current account as a counterpart to the reversal in capital flows; and (iii) the balance sheet problem. The second and third of these had not featured in the crisis literature prior to Krugman. ${ }^{2}$

\section{B. Microeconomic and Institutional Approaches}

The microeconomic approach uses firm level data to investigate corporate performance in crisis countries. It provides evidence to suggest that the causes of the Asian crisis may lie in firm based decisions (see Claessens, Djankov, and Xu, 2000, for a summary of the literature). Four main links between firm level decisions and the crisis appear to be significant. The first is that weak corporate performance after the crisis related largely to the shocks experienced by the Asian countries, including a decline in aggregate demand, the reversal of capital flows, sharp currency depreciation, and an increase in interest rates (Furman and Stiglitz, 1998). ${ }^{3}$

\footnotetext{
${ }^{2}$ Krugman's model is potentially characterized by multiple cquilibria, where a loss of lender confidence, for whatever reason, can lead to a self-fulfilling collapse, although the mechanism differs from that of Diamond-Dybvig (1983). Simply, the loss of confidence leads to the transfer problem and, to achicve the required current account reversal, the country must experience a large real depreciation and/or output decline, either of which adversely affects the balance sheets of domestic firms, thercby validating the initial loss of confidence. Thus, expectations change from a high investment equilibrium to a low investment equilibrium. In this model, the factors that make such a crisis possible-that is, reinforce the feedback loop between investment, real exchange rates and corporate balance sheets-are: (1) high levels of gearing, (2) low marginal propensity to import, and (3) large forcign currency debt relative to exports.

${ }^{3}$ There is some evidence of this from survey data. For example, on the basis of a sample of Thai industrial firms, Dollar and Hallward-Driemeier (2000) found that sixty percent of firms reported that the substantial decline in domestic demand and higher input costs that resulted from the exchange rate depreciation, werc the primary sources of difficulty. Only one-third of the firms cited access to capital as a major hurdle,
} 
Secondly, shocks, whether financial, real, or regulatory, may cause a real or perceived shortage of capital for banks and lead to the curtailing of credit for investment or trade to viable firms with profitable opportunities, thus impairing firm performance. Increased uncertainty regarding whether, and at what price, loans will be available may also result in a shortfall of loanable funds (Stiglitz and Weiss, 1981). The balance-sheet problem (see Bernake and Gertler, 1995) may exacerbate the effect of a shock. Where there is asymmetric information and principal-agent relationships, the net worth (wealth) of a firm becomes the major determinant of the amount it can borrow (as assumed in the Krugman model, 1999) rather than the prospects of the project for which the borrowing is undertaken. Thus a decline in the wealth of a firm, perhaps through depreciation, which decreases the domestic value of foreign assets, can reduce the credit available even for viable new projects.

A third possibility is that the poor performance of the corporate sectors during and after the Asian crisis reflects previous fundamental weaknesses, a view supported by Corsetti and others (1998). This would be why firm performance was not adequately monitored by shareholders and investors and/or firms were not subject to sufficient competition. Thus, poor performers, or riskier firms, were not forced to adjust fully and increase their rates of return to compensate investors for higher risk. This also implics that profitability was overstated by firms and the lack of transparency, relatively wcak accounting practices in the region, and inherently flawed corporate governance, may have hidden the extent of the problems and delayed the onset of the crisis (see Johnson and others, 1998). A number of studies indicate that ownership structure may induce risky behavior. It is well known that the insider system prevails in Asian countries and extensive links and cross-holdings of shares, particularly between the corporate sector and banks, are likely to have distorted the market allocation of resources, because of conflicts of interest, resulting in excessive and non-transparent risk. ${ }^{4}$ Further, the links between the Government and both the corporate and banking sectors has facilitated political intervention in allocation decisions. $^{5}$

Finally, the efficiency of debt resolution mechanisms can determine, in part, the extent of the impact of financial and other shocks. It has long been recognized that the institutional framework is important in avoiding and resolving systemic financial crises and that exceptional mechanisms (such as IMF programs) may be required during periods of systemic crisis. These institutional effects are covered extensively in the literature, and span issues such as the principals of optimal resolution strategies to the importance of creditor rights to enforce claims and seize collateral, both in the context of domestic and external borrowing (for a review, see La Porta and others, 1999). In this paper, we also examine some of these links more closely.

although more cited the cost of capital as a problem. Thus, these shocks played an important but not exclusive role in the performance during the crisis, according to the firms surveyed.

${ }^{4}$ These ownership links clearly played a significant rolc in the Republic of South Korea and Indonesia, with Government involvement through direct participation in bank ownership.

5 Furman and Stiglitz (1998) do point out that even countries with few problems in terms of corporate governance and transparency can still experience crises, for example, Sweden. 


\section{The Malaysian Corporate Sector ${ }^{6}$}

The Malaysian capital market and underlying corporate sector is large with the total capitalization of the Malaysian Stock Exchange (KLSE) of RM 553 billion ( $\$ 145$ billion) or 185 percent of GDP in December 1999 (compared to a peak in 1993 of 360 percent of GDP). ${ }^{7}$ Growth has been rapid, with the number of listed companies rising from 285 in 1990 to 757 by the end-2000, or by an annual average growth rate of over 10 percent (which is faster than the other crisis countries) and market capitalization grew by an average of nearly 30 percent over the same period (while Indonesia and the Philippines experienced higher growth rates, both were from a much lower base). ${ }^{8}$

While the amount of new equity raised was large compared with other countries in the region, Malaysia was still very dependent on bank financing. New financial flows to the corporate sector in the period prior to the crisis (1995-97) were mainly from the domestic banking system, representing nearly 60 percent of net funds (compared to around 15 percent from equity, 11 percent from domestic debt markets, and 16 percent raised as external debt (World Bank, 1999).

Malaysia, like the other crisis countries, is characterized by an insider system of corporate governance, with high levels of ownership concentration, cross holdings and significant participation of owners in management. A few large corporations own a significant proportion of financial assets and productive capacity in Malaysia $;{ }^{9}$ stock ownership is concentrated in the hands of relatively few institutional and corporate investors; and cross-holding of share owncrship, or pyramiding, increases the actual control of a few individuals/entities well beyond their level of ownership in each company. These features of the corporate sector in Malaysia and neighboring countries have resulted in some innate vulnerabilitics. Firstly, the nature of industrial policies of the government has resulted in close ties between government, banks and large corporations. Secondly, the cross-holding structures can create incentives for double gearing, thus creating a multiplier effect in the sensitivity of corporate wealth to changes in the equity market (see Kochhar and others, 1999). Finally, the concentration of shareholding can lead

\footnotetext{
${ }^{6}$ For a more detailed description of the Malaysian corporate environment, see Khatri (2001) and references therein.

${ }^{7}$ The International Finance Corporation's Emerging Stock Markets Factbook for 1999, ranked Malaysia's market capitalization in December 1998 the twenty-third largest in the world, and fifteenth by the number of listed companies.

${ }^{8}$ The growth in market capitalization in Malaysia has been driven mainly by increases in stock prices, but also by new equity issues and privatisation. In the pre-crisis period, only the Republic of Korea raised more through the equity market in absolute terms than Malaysia.

${ }^{9}$ The International Finance Corporation produces concentration indices derived from the largest ten stocks relative to total market capitalization. In December 1998, this was $31.5 \%$ for Malaysia and $61.5 \%, 37.9 \%$, $55.4 \%$, and $45.8 \%$ for Indonesia, the Republic of Korea, the Philippines, and Thailand respectively.
} 
to poor governance as a small group can exercise control over a firm and pursue the objectives of the insiders at the cost of the outsiders, or small shareholders (Claessens, Djankov, Fan, and Lang, 1999).

\section{Corporate Performance Measurement}

Accounting data is used to model corporate performance, and financial ratios constructed as proxies for production relationships. Several examples of this practice exist in the literature such as Jones and others (1998) or Piesse and Townsend (1995). Claessens, Djankov, and Xu (2000) and Harvey and Roper (1999) also use data on listed companies for a range of countries to provide a comparison of performance in the Asian countries with other emerging markets, and major OECD countries (using more conventional measures such as accounting ratios or market returns as well as a measure of efficiency similar to that used here). These studies find evidence that performance (according to a number of measures) in the Malaysian corporate sector, and in the neighboring countries, was already deteriorating prior to the crisis, although dramatically worsened with the onset of the crisis.

This study uses panel data from the balance sheet and income statements provided by the KLSE on 40 publicly listed companies for the period 1995-99. Of these, the financial corporates were excluded because the debt structure of banks and investment institutions is not comparable to that in other sectors. The remaining firms represented the consumer goods, industrial products, construction, trade, technology and plantation sectors.

We measure corporate performance by estimating firm level efficiency using a stochastic production frontier model with inefficiency effects (discussed in the next section). Output is endogenous and represented by total sales, revenue or turnover. Independent variables include labor, capital and debt-related measures. Total assets are used as a proxy for capital. Alternative constructions of the capital variable, such as the perpetual inventory method, were not viable due to the lack of information on depreciation and real investment. Problems such as these are common when using accounting data and the use of the capital stock is quite normal. Labor and other inputs are approximated by general expenses, since the income statements did not breakdown expenses into labor and other type of expenses.

The level of indebtedness is very important in this study since the high levels of debt, particularly from foreign providers, have been proposed as a major cause of the financial crises in Asia. Three variables are included to assess the extent of borrowing and of the impact of interest payments on the financial exposure of the companies in this sample. First, the firms' debt structure is reflected in the traditional gearing ratio of long-term debt to shareholders funds, which by implication, is a risk variable. Second, interest cover is a measure of the number of times the interest payable is covered by profits available for such payments. Both debt holders and shareholders hope to see a high interest cover ratio: for the former it is a measure of the protection they have during periods of falling profits and the latter wish to maximize their potential dividend. Finally, the total debt to assets ratio is a good indicator of the extent of unsecured lenders, since this includes all debts, including those to trade creditors that can be a large part of the short-term debt levels. 
To model the inefficiency effects linked to governance, we use two firm level characteristics drawn directly from the finance literature, namely the nature of corporate debt and the degree of shareholder concentration. Thus, we construct one debt variable and one variable that defines the pattern of ownership. To capture the role of debt in ensuring good governance, we use the share of total debt that is short-term. Long-term debt can be an important mechanism of control and systems of governance that are debt-based have been used (see Jensen, 1983). Firms that do not have long-term debt as part of their capital structure are not accountable to providers of capital, whether bond holders or banks. Furthermore, much of the short-term debt that consists of overdrafts may be an attempt to cover a shortfall in resources rather than part of a long-term strategy for capital provision. In either case, the ratio of total debt that is short-term is expected to be a contributing factor to the inefficient performance of firms.

An indicator of shareholder concentration is central to our proposed micro-economic analysis of financial crises. In a corporate governance context, the question of how to measure the extent to which a company is controlled by individual or groups of shareholders has been the subject of much debate. One simple approach, based on a Herfindahl-type methodology, consists of computing the simple proportion of total shareholding held by the largest direct shareholders, or the sum of the square of the percentage of shares they hold. However, it can easily be shown that this methodology has severe limitations when applied to an "insider" model characterized, as it is in Asia, by cross-holding and complex pyramidal structures. In fact, even in an "outsider" model, the Herfindahl approach has many shortcomings (see Crama and others, 1999)..$^{10}$

An alternative approach is to build indices of corporate control that provide consistent estimates of ownership dispersion, within a game theoretic framework. Here, shareholders are modeled as players in a voting game using classical power indices (such as Shapley indices, as discussed in Owen, 1982) to measure each shareholders' relative ability to impose their will through coalitions with other shareholders. The Zeno Index, proposed by Crama and others (1999) belongs to that family. It is based on the Banzhaf index, where the index of a single shareholder is defined as the number of times the sharcholder can swing an outcome by changing his or her mind (all others unchanged). ${ }^{11}$ The Zeno Index adds some useful dimensions to the Banzhaf index however, that make it more suitable to our analysis. First, the methodology used makes it possible to compute the index in large systems (whereas the Banzhaf would require the computation of $2^{\mathrm{N}}$ votes where

\footnotetext{
${ }^{10}$ First, the expectation in a typical Herfindahl index is that any dilution of shareholding will lead to a lesser concentration level, but this is not necessarily the case if two or more of the lower ranked shareholders collude, an cvent not incorporated into the Herfindahl construction. Second, since the emphasis is on the larger shareholders only, the potentially disciplinary effect of collusion amongst smaller or floating shareholders is ignored. Finally, the Herfindahl indices can only deal with one layer of shareowners and so cannot deal with multi-layered structures, even when they are simple, let alone those commonly found in Asia.

${ }^{11}$ See Banzhaf (1966). For a discussion of the link between the Shapley value and the Banzhaf index, see Dubey and Shapley (1979).
} 
$\mathrm{N}$ is the number of shareholders in the system). ${ }^{12}$ Secondly, the Zeno also integrates the possibility of coalitions by small shareholders (the float) who can therefore influence the outcome of the game. ${ }^{\mathrm{t}}$

Summary statistics for these data are reported in Table 1, with their corrclations. The size of the standard deviations in the data show there is ample variance across the sample to enable estimation. Some of the correlation coefficients are very high, which is a common problem in accounting data. For example, sales are highly correlated with labor and other expenses, which is not surprising. The correlation between the two ownership variables, the proxy and the Zeno Index is low and often negative. This is supported in the results section, where the latter is found to be a more useful metric.

Table 2 provides an indication of the trends of the data, showing annual means and dispersion. The nominal value of sales increases from 1995 to 1998, but falls in 1999 due to reduced consumer demand following the crisis. Labor and other costs follow the same trend; with lower expenditure in 1999 reflecting the widespread cost cutting and labor shedding that resulted from the crisis. The level of total debt has risen sharply as indicated by the total debt/total assets ratio. As is shown in Table 2, although total assets rose, this ratio nevertheless increased by $50 \%$ over the period. The mean level of the gearing ratio has risen throughout the period. The dispersion is also increasing, implying that all firms are increasing their debt levels although it is not clear whether this is an indication of prudence in the face of an expected credit shortage and subsequent high interest rates on the part of some, or a shift to short term credit that may be manipulated more easily. Since gearing is increasing, interest provision falls, as expected. The share of short-term to total debt is high throughout, but stays fairly constant.

\section{MeaSURing FirM-LEVEL EFFICIENCY USING Stochastic Frontiers WITH INEFFICIENCY EFFECTS}

The objective is to derive an economic measure of firm performance - namely efficiency. There are two main approaches in the literature to define efficiency as the (relative) distance of a firm from some "best practice" frontier: the nonparametric approach which relies on indices or data envelopment analysis (DEA); and the parametric approach, which requires econometric estimation of the best practice frontier. The former has the advantage of not requiring explicit specification of the form of the production relationship, and does not have a stringent minimum sample requirement (e.g. can be done for two firms). However, we also would like to model the factors that explain inefficiency, which can only be done using the parametric approach.

\footnotetext{
${ }^{12}$ Even in a small Stock Exchange with 150 firms and 300 not quoted shareholders (about the size of the Brussels Stock Exchange, and not taking into account small shareholders), this would mean the computation of nearly $2^{450}$ strings of votes (some of them would of course be irrelevant, but the number would remain excessively large for practical purposes).

${ }^{13}$ For a more detailed discussion of these and other issues, see Crama and others (1999) and the references thercin.
} 
The parametric approach has become increasingly commonplace with the development of frontier production functions and their availability as options on statistical packages. The approach can be deterministic (where all deviations from the frontier are attributed to inefficiency) or stochastic, which is a considerable improvement, since it is possible to discriminate between random errors and differences in (in)efficiency. This paper uses a stochastic frontier model, of the type originally proposed by Aigner, Lovell, and Schmidt (1977), ${ }^{14}$ extended, as in the work of Battese and Coelli (1995), to include characteristics of the firm that explain inefficiency.

Relative efficiency can be measured by applying stochastic frontier techniques to the individual annual samples, and to the total sample as a panel, but in many cases efficiency differences are a function of inadequate models and data, even when the frontier is stochastic. These two potential difficulties are directly addressed here. First, in many cases, model error is likely because the functional form fitted is often the highly restrictive Cobb Douglas. Thus, the adequacy of the Cobb Douglas should be tested against a flexible functional form, such as the translog. Second, data error is inevitable where a model essentially representing economic production relies on accounting data, although a number of precedents do exist in the literature, for example in Jones and others (1998) and Piesse and Townsend (1995). Apart from measurement error embodied in the available variables, failure to adjust for serious differences in quality of capital and labor, the omission of important variables and inappropriate aggregation can also affect the analysis. In addition, a third problem has been highlighted by Smith (1997) who has shown that inefficiency levels, or choice of frontier over the average production function, depend on both the functional form and the level of aggregation, even if there are no missing variables.

For all these reasons, inefficiencies need to be treated with a degree of caution and appropriate tests are required to select the correct model as in Battese and Coelli (1995). Their model, in which the efficiency differences are simultaneously estimated from the stochastic frontier and explained by further variables, incorporates tests that choose between functional forms and between frontier and average models.

The general form of the panel data version of Aigner and others' (1977) production frontier, with inefficiency effects, is stated by Coelli and others (1998) as:

$$
\begin{gathered}
y_{i t}=f\left(x_{j, i}, t, \beta\right)+\varepsilon_{i t} \quad \text { where } \varepsilon_{i}=V_{i t}-U_{i t} \\
\text { with } U_{i t} \sim\left|N\left(m_{i t}, \sigma_{U}^{2}\right)\right| \text { and } V_{i t} \sim N\left(0, \sigma_{V}^{2}\right)
\end{gathered}
$$

where $f($.$) is a suitable functional form, y_{i t}$ is the output of firm $i$ at time $t, x_{j}$, it is the corresponding level of input $j$ and $\beta$ is a vector of parameters to be estimated. The $V_{i t}$ 's are independently and identically distributed random error terms and uncorrelated with the regressors. The $U_{i t}$ 's are non-negative random variables associated with the technical inefficiency of the firm. ${ }^{15}$ In the second part of the model, this inefficiency term, $U_{i t}$, is made an

\footnotetext{
14 See Fried and others (1993) for a comprehensive survey of methods and applications.

Is If the residuals are negatively skewed, the maximum likelihood estimator for the stochastic frontier production function model is simply OLS (see WaIdman, 1992). In this case, either the model is misspecified or the data are not consistent with the functional form.
} 
explicit function of $k$ explanatory variables, $z_{k, i t}$, associated with the nature of governance in South-East Asia. The $\mathrm{U}_{\mathrm{it}}$ are independently, but not identically, distributed as non-negative truncations of the normal distribution of the form:

$$
U_{i t} \sim N\left[\delta_{0}+\sum_{k=1}^{M} \delta_{k} z_{k, i t}, \sigma^{2}\right]
$$

The method of maximum likelihood is used to estimate the unknown parameters, with the stochastic frontier and the inefficiency effects estimated simultaneously. A number of related models can be tested for following the estimation. For example, if the coefficient of the first $z$-variable (the constant) has the value one and the coefficients of all other $z$-variables are zero, this represents the model specified in Stevenson (1980). Alternatively, if all elements of the $\delta$ vector are equal to zero, the technical inefficiency effects are not related to the $z$-variables and the half-normal distribution specified by Aigner and others (1977) results.

The technical efficiency of an individual firm is defined in terms of the ratio of the observed output to the corresponding frontier output, conditional on the levels of inputs used by that firm. Thus, the technical efficiency of firm $i$ at time $t$ in the context of the stochastic frontier production function can be expressed in terms of the errors as:

$$
T E_{i t}=E\left[\exp \left(-U_{i t}\right) \mid\left(V_{i t}-U_{i t}\right)\right]
$$

which is the expectation of the exponentiated technical inefficiencies, conditional on the error, $\varepsilon_{\mathrm{it}}$. Since $U_{i t}$ is a non-negative random variable, these technical efficiencies lie between zero and unity, where unity indicates that this firm is technically efficient. Coelli and others (1998) show that technical efficiency of firm $i$ at time $t, T E_{i t}=D^{t}\left(y_{i}^{t}, x_{i}^{t}\right)$, is the distance function at time $t$.

\section{Models, Estimation, And Hypothesis Tests}

The output variable (y), the inputs (x's) and factors explaining inefficiency (z's) were described in Sections 3. The functional form of the stochastic frontier was determined by testing the adequacy of the Cobb Douglas relative to the less restrictive translog. Thus, the frontier models estimated are defined as:

$$
y_{i t}=\beta_{o}+\sum_{j=1}^{5} \beta_{j} x_{j i t}+V_{i t}-U_{i t}
$$

and

$$
y_{i t}=\beta_{0}+\sum_{j=1}^{5} \beta_{j} x_{j t}+\sum_{j=1}^{5} \sum_{h=1}^{5} \beta_{j h} x_{j i t} x_{h i t}+V_{i t}-U_{i t}
$$

respectively. Thus, the technological change index in equation (5) is based on the coefficients of time, time squared and the interaction of time with the four inputs, which is data-dependent. This allows fully for the non-linear effects that are to be expected during the crisis.

In the second part of the model, the inefficiency effects follow from equation (2), provided these effects are stochastic and not merely a deterministic function of the relevant explanatory variables. Thus, the mean inefficiencies for each firm, $m_{i t}$, are explained by the $z$ variables 


$$
m_{i t}=\delta_{0}+\sum_{k=1}^{K} \delta_{k} \quad z_{k i t}
$$

although this function may not be estimable in all cases.

The maximum-likelihood estimates of the parameters in the Cobb-Douglas and translog stochastic frontier production function models defined by (4) and (5), given the specifications for the technical inefficiency effects defined in (6), were obtained using FRONTIER 4.1 (Coelli, 1994). Hypothesis tests based on the generalized Likelihood Ratio (LR) test ${ }^{16}$ were conducted to select the functional form and to determine the presence of inefficiencies.

The first test reported in Table 3 is the selection of the functional form, where the null hypothesis is that the Cobb-Douglas is an adequate representation of the data. The LR test indicates that the Cobb Douglas is accepted indicating that the more general form of the translog is not appropriate for these data.

The lower part of Table 3 reports the results of LR tests of the hypothesis that the technical efficiency effects are not simply random errors. The key parameter is $\gamma=\sigma_{\mathrm{u}}{ }^{2} / \sigma^{2}$, which is bounded by zero and one. If $\gamma=0$, technical inefficiency is not present; hence, the null hypothesis is that $\gamma=0$, indicating that the mean response function (OLS) is an adequate representation of the data. The closer $\gamma$ is to unity, the more likely it is that the frontier model is appropriate. The power of the LR test is increased by testing jointly the null hypothesis that $\gamma=\delta_{i}=0$, for all $\mathrm{i}$, meaning that neither the constant term nor the inefficiency effects are present in the model. ${ }^{17}$ Four models were selected and subjected to the test described above.

The frontier models differ in the choice of debt variable. In model 1, asset cover measures the total debt to assets status of the firm. Models 2, 3 and 4 include the traditional gearing ratio that reflects the capital structure strategy of the firm. In model 4 a sector dummy was also included. With respect to the inefficiency aspects of the models, a measure of the composition of the maturity of debt was included by incorporating the share of short-term to total debt and an index indicating ownership concentration.

\section{A. Estimation and Tests}

The results of tests conducted on the four models are reported in Table 3 . The functional form of the stochastic frontier was determined by testing the adequacy of the log-linear model relative to

\footnotetext{
${ }^{16}$ The likelihood-ratio test statistic, $\lambda=-2\left\{\log \left[\right.\right.$ Likelihood $\left.\left.\left(\mathrm{H}_{0}\right)\right]-\log \left[\operatorname{Likelihood}\left(\mathrm{H}_{1}\right)\right]\right\}$ has approximately $\chi_{\mathrm{q}}^{2}$ distribution with q equal to the number of parameters assumed to be zero in the null hypothesis.

${ }^{17}$ Since $\gamma$ takes values between 0 and 1 , any LR test involving a null hypothesis which includes the restriction that $\gamma=0$ has been shown to have a mixed $\chi^{2}$ distribution, with appropriate critical values (Kodde and Palm, 1986).
} 
the less simplistic translog, which includes cross products and square terms to allow for interactions and non-linearity in the data (Table 3, test 1). In all the models, the log linear model was accepted as an adequate representation of these data because multicollinearity (evident in Table 1) prevented convergence in the translog form.

The next test is to determine whether this is indeed a frontier model and not simply a mean response function (MRF) or OLS. A weak criterion is a t-test on the estimated parameter, $\gamma$. The closer this is to unity, the more likely it is that the frontier model is appropriate. In all cases $\gamma$ is significantly different from zero and, in model $1, \gamma$ is close to one, as reported in Table 3, test $2 \mathrm{a}$. This implies that one or more of the firms in the sample are fully efficient, that is, they form a frontier of best practice, while the remainder are found to be some measurable distance from this efficiency frontier. The more robust $\log$ likelihood ratio test (LR) test found that models 2,3 and 4 are frontiers while model 1 is a mean response function, as reported in Table 3 , test $2 \mathrm{~b}$. This means that the model reduces to OLS with the ownership concentration proxy as a normal explanatory variable.

Finally, the power of the LR test is increased by testing jointly the null hypothesis that both the frontier parameter and all the inefficiency effects are jointly zero, i.e. that the inefficiency effects are not present in the model. These results are reported in Table 3, test 3 . The result of this test confirms that all the governance variables are important in explaining firm performance.

\section{B. Results and Discussion}

All four models were estimated in order to test the relative effectiveness of alternative debt and corporate governance variables in explaining output and inefficiency. The maximum likelihood estimators are reported in Table 4. In the frontier, the variables measuring capital and labor expenses are common to all models and are positive and significantly different from zero. Since the coefficients in a linear model are the output clasticities, the inference is that a $1 \%$ increase in of total assets will result in an increase in total revenue of more than $0.5 \%$. Similarly, a $1 \%$ increase in labor expenses increased total revenue by between $0.17 \%$ and $0.23 \%$. These are the basic capital and labor inputs in the determination of firm productivity.

We now turn to the remaining variables. In model 1 , the effect of debt measured by asset coverage for total outstanding loans has an elasticity of only -0.09 , although it is negative and significant. This debt variable has more effect in model 2 , which also has a further debt-related inefficiency effect and includes the Zeno ownership concentration index. The negative impact of debt, as measured by gearing in models 3 and 4, is higher (again both use the proportion of shortterm debt and the Zeno Index). It is clear that in these last two models $1 \%$ increase in the level of gearing reduces total revenue by $0.47 \%$ and $0.35 \%$, respectively. In all cases, the interest provision term is positive and significant, which is useful as default on interest payments denotes major corporate distress. The only significant industry dummy is that on the Consumer Products sector, included in model 4, which is probably due to the importance of the impact of the crisis on disposable income. This variable simply raises the intercept by an additional constant term, stating that compared with the other sectors, consumer products has overall higher levels of productivity. Including this variable improves the log likelihood statistic significantly, making model 4 the preferred model 
The governance factors that explain firm level inefficiencies are reported in the lower part of Table 4. Since the dependent variable in this section of the model is inefficiency, the positive coefficients (ignoring the constant term, which is negative) show that all three variables are increasing the level of inefficiency. Note that these cannot be interpreted straightforwardly as elasticities, and are more like weights. First, short-term debt, either at the expense of creditors, or in the form of rolled-over bank overdrafts, is highly significant in models 2,3 and 4 . Therefore, in model 2 , the inclusion of the asset coverage variable that already takes account of the short term, results in a lower coefficient on the debt variable in the inefficiency model when compared with 3 and 4 (where the gearing is a long-term debt measure). These three specifications all show strong support for the view that both the extent and the providers of debt play a central role in firm performance. One interpretation is that debt can be manipulated between short and longterm creditors and there is a heavy reliance on bank funding that results in major differences in efficiency for these firms.

The other governance variable in the inefficiency models reflects concentration of ownership and control. Both representations are positive and significant, confirming that the extent of ownership concentration is important in explaining firm inefficiency. As noted above, the rather naïve measure in model 1 is significant, although this is not found to be a frontier model and thus it can be viewed as another factor influencing the production function. In models 2,3 and 4 both the share of short-term debt and the Zeno index are important in explaining inefficiencies. Although the weighting on the Zeno index in model 2 is low, it is still preferred as the alternative understates true concentration (as discussed above), and notwithstanding that the game theoretic index is more appropriate as it takes into account the possibility of collusion. The Zeno index works equally well, even when the total debt measure is an explanatory variable in the frontier. The high significance and explanatory power of the ownership concentration variables provides evidence of a robust and positive relationship between the system of crossshareholding and ownership concentration that exists in Malaysia and the measured inefficiency in the corporate sector. ${ }^{18}$

The annual individual firm level efficiency measures are derived from the stochastic frontier model, and represent that part of the error term that is not stochastic. These are reported in Table 5. Since the maximum efficiency level is obviously unity, or $100 \%$, the table indicates that the average level of efficiency in 1995 is between $75 \%$ and $78 \%$, depending on the model specification. For the three years prior to the crisis in 1998, this increased. In the year of the crisis, the mean efficiency level has fallen, and the dispersion level rises, as some firms, and some sectors, are more vulnerable than others. Finally, in 1999 efficiency is shown to be higher in all specifications than before the crisis as many firms recovered either by debt rescheduling or by shedding labor. This recovery is clearly seen in Figure 1.

\footnotetext{
${ }^{18}$ Crama and others (1999) find similar strong explanatory power of the Zeno index in equations explaining share price or beta values of listed companies in the UK. Note too that they also show the importance of the control held by the second largest sharcholder in explaining firm's performance.
} 


\section{Figure1. Mean Efficiency Levels}

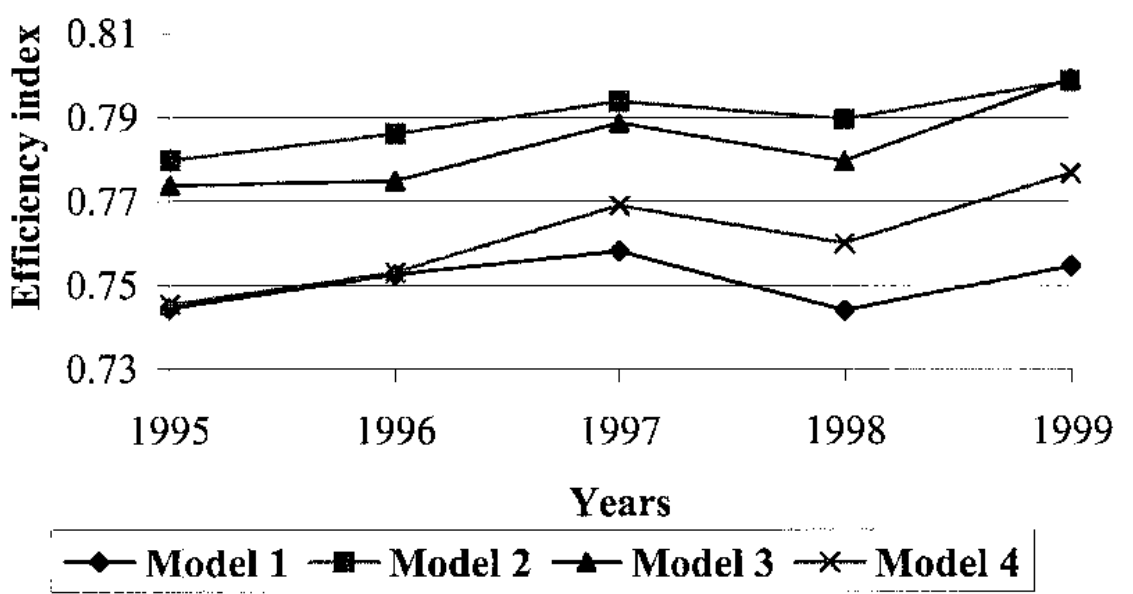

However, the overall level of efficiency does not indicate a fully competitive economy, as the overall inefficiency level remains higher than $20 \%$. Further years of data for this sample may show this no longer is a frontier model as some of the reforms discussed in Khatri (2001) are implemented.

The current reform of the corporate sector in Malaysia involves debt restructuring, operational restructuring, and reform of corporate governance environment (see Khatri, 2001 for a review of the notable progress made in these areas following the crisis). From the point of view of these results, it is reform in the systems of corporate governance that will improve corporate performance and reduce vulnerability. Good rules of corporate governance make a difference in helping markets distinguish between fundamentally sound firms and those that are not competitive through increasing transparency with respect to firm operations and performance, clarifying responsibilities of senior managers, addressing conflicts between the interests of crossshareholders and through the protection of minority shareholders. In general, Malaysian authorities are attempting to improve corporate governance through the implementation of a series of recommendations in the Report on Corporate Governance compiled by the High Level Finance Committce on Corporate Governance (this committee was set up after the crisis to review and improve the corporate governance environment). Our sample ends in 1999, and thus does not capture the bulk of post-crisis corporate governance reforms, and any associated improvements in firm performance.

Finally, while Malaysia is a competitive economy, there are rigidities and it is one of the few middle-income countries without a competition law. One result of this can be seen in the efficiency levels reported in Table 5, and the planned competition and consumer law, in line with international best practice, will exert market pressure on the corporate sector to reduce costs and improve efficiency in the future. 


\section{Conclusions}

This paper discussed the links between financial crises and the corporate sector. A stochastic frontier model with inefficiency effects has been used to examine the impact of corporate balance sheets on the effects of the crisis, within an environment of weak corporate governance characterized by a concentrated ownership structure and poor debt management. The results indicate that both of these increase the probability that firms will be operating away from the best practice frontier, and thus their susceptibility to crisis. The post-crisis corporate governance reforms, if effectively implemented, can be expected to improve firm performance.

As an endnote, we would like to stress the problems associated with a banking system closely linked to the corporate sector, as is the case in Malaysia. In an outsider system, debt holders are external to the firm and, by issuing debt, managers are bonding their promise to pay out future cash flows as they mect their obligation to pay interest before dividends. Hence, in an outsider system of control, high levels of gearing are a compensating control mechanism, as suggested by Jensen (1983). Indeed, the threat caused by failure to service debt serves as an incentive to increase efficiency and productivity. However, in the case of Malaysia and most other countries with an insider model of corporate governance, this seems to be an unlikely outcome. Providers of fixed income capital in an insider system are banks that, as part of an insider system, also often have a direct interest in the firm, or close links (such as family members) to their directors. As a consequence, this feature prevents debt from acting as the compensating mechanism. 
Table 1. Summary Data Statistics and Correlation Coefficients ${ }^{\mathrm{a}}$

\begin{tabular}{|c|c|c|c|c|c|c|c|c|c|c|}
\hline Variable & Mean & Std Dev & 1 & 2 & 3 & 4 & 5 & 6 & 7 & 8 \\
\hline 1 Sales & 2934312 & 2781967 & 1 & & & & & & & \\
\hline 2 Total assets & 6394577 & 8674438 & 0.78 & 1 & & & & & & \\
\hline 3 Labor and other expenses & 200175 & 279378 & 0.79 & 0.93 & 1 & & & & & \\
\hline 4 Total debt/Total assets & 0.23 & 0.19 & 0.32 & 0.50 & 0.45 & 1 & & & & \\
\hline 5 Gearing ratio $(\%)$ & 41.49 & 73.20 & 0.27 & 0.50 & 0.38 & 0.74 & 1 & & & \\
\hline 6 Interest provision & 60.48 & 148.68 & -0.02 & -0.03 & 0.02 & -0.13 & -0.07 & 1 & & \\
\hline 7 Short-term debt/Total debt & 52.02 & 36.49 & -0.20 & -0.33 & -0.03 & -0.29 & -0.44 & 0.14 & 1 & \\
\hline 8 Owner concentration proxy & 0.76 & 0.14 & 0.10 & 0.11 & 0.10 & 0.14 & -0.01 & -0.09 & 0.13 & 1 \\
\hline 9 Zeno Index & 0.66 & 0.38 & 0.15 & 0.17 & 0.20 & -0.12 & -0.10 & 0.08 & -0.13 & -0.34 \\
\hline
\end{tabular}

${ }^{a}$ Correlations $> \pm 0.14$ are significant at $95 \%$ confidence 
Table 2. Trends in Variables: Annual Means and Standard Deviations

\begin{tabular}{|c|c|c|c|c|c|c|c|c|c|c|}
\hline & \multicolumn{5}{|c|}{ Mean } & \multicolumn{5}{|c|}{ Standard Deviation } \\
\hline & 1995 & 1996 & 1997 & 1998 & 1999 & 1995 & 1996 & 1997 & 1998 & 1999 \\
\hline & \multicolumn{10}{|c|}{ (In thousands of ringgit) } \\
\hline Sales & $2,269,584$ & $2,696,096$ & $3,244,799$ & $3,339,042$ & $3,122,041$ & $2,178,555$ & $2,503,271$ & $3,019,868$ & $3,181,168$ & $2,942,138$ \\
\hline Total assets & $4,106,794$ & $5,604,646$ & $7,177,443$ & $7,238,685$ & $7,845,319$ & $5,541,583$ & $7,788,974$ & $9,952,884$ & $9,217,036$ & $10,063,481$ \\
\hline Labor and other expenses & 134,707 & 186,989 & 247,096 & 259,387 & 172,695 & 158,583 & 225,996 & 339,728 & 340,679 & 285,799 \\
\hline & \multicolumn{10}{|c|}{ (In percent) } \\
\hline Total debt/Total assets & 18 & 21 & 24 & 26 & 27 & 18 & 19 & 20 & 20 & 20 \\
\hline Gearing ratio & 23 & 35 & 41 & 44 & 64 & 37 & 63 & 60 & 66 & 89 \\
\hline Interest provision & 84 & 64 & 86 & 33 & 36 & 147 & 161 & 213 & 89 & 101 \\
\hline Short-term/total debt & 56 & 53 & 48 & 49 & 53 & 36 & 39 & 37 & 37 & 34 \\
\hline
\end{tabular}


Table 3. Model Hypothesis Tests ${ }^{\mathrm{a}}$

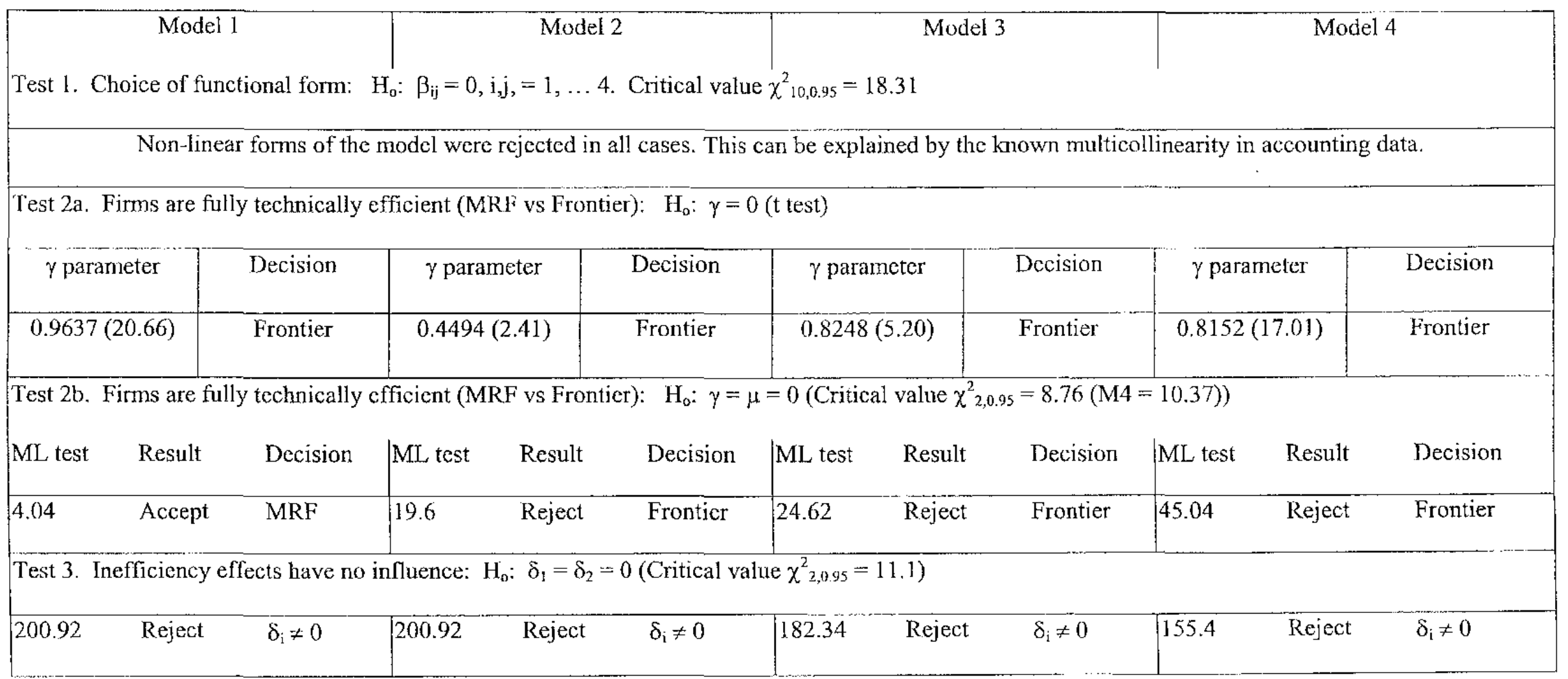

${ }^{3}$ Critical values are from Kodde and Palm (1986) who note that since $\gamma$ takes values between 0 and 1 , any LR test involving a null hypothesis

which includes the restriction that $\gamma=0$ has been shown to have a mixed $\chi^{2}$ distribution, with appropriate critical values. 
Table 4. Maximum-Likelihood Estimates (t-statistics) ${ }^{\mathrm{a}}$

\begin{tabular}{|c|c|c|c|c|}
\hline $\begin{array}{l}\text { Regressors in the Performance Frontier Models } \\
\text { (Dependent variable }=\text { Total Revenue) }\end{array}$ & Model 1 & Model 2 & Model 3 & Model 4 \\
\hline Constant & $4.8726(6.70)$ & $4.3313(5.10)$ & $4.5290(6.51)$ & $4.1334(6.38)$ \\
\hline Total Assets & $0.5467(6.95)$ & $0.5624(6.59)$ & $0.5068(7.31)$ & $0.5660(8.75)$ \\
\hline Labor and Other Expenses & $0.1708(2.80)$ & $0.1973(3.03)$ & $0.2323(3.79)$ & $0.1762(3.19)$ \\
\hline Asset Coverage for Outstanding Loans & $-0.0949(-1.98)$ & $-0.1381(-2.71)$ & & \\
\hline Gearing ratio & & & $-0.4696(-2.82)$ & $-0.3459(-2.22)$ \\
\hline Interest Provision & $0.1468(1.78)$ & $0.2571(3.46)$ & $0.2198(2.87)$ & $0.2205(3.36)$ \\
\hline Sector Dummy (Consumer goods) & & & & $0.6342(5.64)$ \\
\hline \multicolumn{5}{|l|}{ Governance Factors in the Inefficiency Models } \\
\hline Constant & $-2.3073(-0.95)$ & $-4.0459(-2.14)$ & $-5.4152(-1.96)$ & $-7.22424(-2.83)$ \\
\hline Share of Short-term debt & & $0.8684(2.05)$ & $2.4675(2.33)$ & $3.7874(3.22)$ \\
\hline Ownership Concentration proxy & $3.5303(2.80)$ & & & \\
\hline Zeno Index & & $3.8129(2.15)$ & $3.6600(2.07)$ & $4.0819(2.74)$ \\
\hline Loglikelihood statistic & -142.536 & -134.785 & -133.540 & -119.145 \\
\hline
\end{tabular}

${ }^{a}$ Critical value of two-tailed test $=2.01$ at $95 \%$ significance and 1.7 at $90 \%$ significance 
Table 5. Firm-Level Effíciency Levels: Annual Means and Pancl

\begin{tabular}{|c|cccc|cccc|}
\hline & \multicolumn{5}{|c|}{ Mean } & \multicolumn{3}{c|}{ Standard Deviation } \\
\hline \multirow{2}{*}{1995} & Model 1 & Model 2 & Model 3 & Model 4 & Model 1 & Model 2 & Model 3 & Model 4 \\
1996 & 0.76 & 0.78 & 0.77 & 0.75 & 0.10 & 0.16 & 0.17 & 0.18 \\
1997 & 0.75 & 0.79 & 0.78 & 0.75 & 0.09 & 0.16 & 0.17 & 0.18 \\
1998 & 0.76 & 0.79 & 0.79 & 0.77 & 0.10 & 0.14 & 0.16 & 0.17 \\
1999 & 0.74 & 0.79 & 0.78 & 0.76 & 0.13 & 0.16 & 0.18 & 0.18 \\
Pancl & 0.76 & 0.80 & 0.80 & 0.78 & 0.12 & 0.14 & 0.15 & 0.16 \\
& 0.75 & 0.79 & 0.78 & 0.76 & 0.11 & 0.15 & 0.16 & 0.17 \\
\hline
\end{tabular}




\section{References}

Aigner, D., C. Lovcll, A. Knox, and P. Schmidt, 1977, "Formulation and Estimation of Stochastic Frontier Models," Journal of Econometrics, 6 (1), pp. 21-37.

Banzhaf, J.F., 1966, "Multi-member Electoral Districts - Do They Violate the 'One Man-One Vote' Principle?," Yale Law Journal, 75, pp. 1309-38.

Battese, G., and T. Coelli 1995, "A Model for Technical Inefficiency Effects in a Stochastic Frontier Production Function for Panel Data," Empirical Economics, 20, pp. 325-32.

Berg, A., E. Borensztein, G.-M. Milesi-Ferretti, and C. Pattillo, 1999, Anticipating Balance of Payments Crisis: The Role of Early Warning Systems, IMF Occasional Paper No.186 (Washington: International Monetary Fund).

Bernake, B., and M. Gertler, 1995, "Inside the Black Box: The Credit Channel of Monetary Policy Transmission," Journal of Economic Perspectives, 9 (4), pp. 27-48.

Chang, R., and A. Velasco, 1998, "Financial Crisis in Emerging Markets: A Canonical Model", NBER Working Paper No. 6606 (Cambridge, Massachusetts: National Bureau of Economic Rescarch).

Claessens, S., S. Djankov, and L. Lang 1998, "Who Controls East Asian Corporations?", World Bank Working Paper (Washington).

Claessens, S., S. Djankov, J. Fan, and L. Lang 1999, "Corporate Diversification in East Asia: The Role of Ultimate Ownership and Group Affiliation", World Bank Policy Research, Working Paper No. 2089 (Washington).

Claessens, S., S. Djankov and D. Klingebiel 1999, "Bank and Corporate Restructuring in East Asia: Opportunities for Further Reform", Background Paper for the IMF Annual Meetings Seminar, September.

Claessens, S., S. Djankov, and L. Xu, 2000, "Corporate Performance in the East Asian Financial Crisis," The World Bank Research Observer, 15 (1), pp. 23-46.

Coelli, T., 1994, FRONTIER Version 4.1: A Computer Program for Stochastic Frontier Production and Cost Function Estimation, (unpublished; Armidale, NSW, Australia: Department of Econometrics, University of New England).

Coclli, T., P. Rao, and G. Battese, 1998, An Introduction to Efficiency and Productivity Analysis (Boston, Mass: Kluwer Academic Publishers).

Corsetti, G., P. Pesenti, and N. Roubini, 1998, "What Caused the Asian Currency and Financial Crisis? A Macroeconomic Overview", NBER Working Paper No. 6833 (Cambridge, Massachusetts: National Bureau of Economic Research). 
Crama Y., L. Leruth L, L. Renneboog, and J.-P. Urbain, 1999, "Corporate Governance Structures, Control and Performance in European Markets: A Tale of Two Systems", Center for Operations Research and Econometrics (CORE) Discussion Paper No. 9942 (UCL, Belgium).

Diamond, D. and P. Dybvig, 1983, "Bank Runs, Deposit Insurance, and Liquidity," Journal of Political Economy, 91, pp 401. 419.

Dollar, D. and M. Hallward-Driemeier, 2000, "Crisis, Adjustment, and Reform in Thailand's Industrial Firms," The World Bank Research Observer, 15 (1), pp. 1-22.

Dubey, P. and L. Shapley, 1979, "Mathematical Properties of the Banzhaf Power Index," Mathematics of Operations Research, 4 (2).

Eichengreen, B., A. Rose, and C. Wyplosz, 1996, "Contagious Currency Crises: First Test," Scandinavian Journal of Economics, 98 (4), pp. 463-484.

Fried, H., C. Lovell, A. Knox, and S. Schmidt, 1993, The Measurement of Productive Efficiency: Techniques and Applications (New York: Oxford University Press).

Furman, J. and J. Stiglitz, 1998, "Economic Crises: Evidence and Insights from East Asia," Brookings Papers on Economic Activity, 2, pp. 1-135.

Greene, W., 1980, "Maximum Likelihood Estimates of Econometric Frontier Functions," Journal of Econometrics, 13, pp. 27-56.

Harvey, C. and A. Roper, 1999, "The Asian Bet," in Harwood, Litan Pomerleano (Eds), The Crisis in Emerging Financial Markets, Brookings Institution Press, pp. 29-115.

Jensen, M., 1983, "Agency Costs of Free Cash Flow, Corporate Finance, and Takeovers," American Economic Review, Papers and Proceedings, 76 (2), pp. 323-329.

Johnson, S., P. Boone, A. Breach, and E. Friedman, 1998, "Corporate Governance in the Asian Financial Crisis", 1997-98, MIT, mimeo.

Jones, D., M. Klinedinst, and C. Rock C 1998, "Productive Efficiency during Transition: Evidence from Bulgarian Panel Data," Journal of Comparative Economics, 26 (3) pp. 446-64.

Khatri, Y., 2001, "Malaysia: Corporate Performance and Reform", in Malaysia: From Crisis To Recovery, IMF Occasional Paper 207.

Kochhar, K., 1999, Malaysia: Selected Issues, IMF Country Report, 99/86.

Kodde, D. and F. Palm, 1986, "Wald Criteria for Jointly Testing Equality and Inequality Restrictions," Econometrica, 54 (5), pp. 1243-1248.

Krugman, P., 1979, "A Model of Balance of Payments Crisis," Journal of Money, Credit and Banking, 11, pp. 311-325. 
, 1998, "What Happened to Asia?" (January) MIT, Cambridge. Available At http://web.mit.edu/krugman/www/disinter.html

, 1999, "Balance Sheets, the Transfer Problem, and Financial Crises", draft prepared for the Festschrift Volume in honor of Robert Flood, MIT, Cambridge. Available At http://web.mit.edu/krugman/www/ttother

La Porta, R., F. Lopez-de-Silanes, and A. Shleifer, 1999, "Investor Protection: Origins, Consequences, Reform", NBER Working Paper No.7428, pp. 1-42 (Cambridge, Massachusetts: National Bureau of Economic Research).

Obstfeld, M., 1986, "Rational and Self-Fulfilling Balance of Payments Crises," American Economic Review, 76, 72-81

Owen, G., 1982, Game Theory (New York: Academic Press).

Piesse, J. and R. Townsend, 1995, "The Measurement of Productive Efficiency in UK Building Societies," Applied Financial Economics, 5 (6), pp. 397-407.

Radelet, S. and J. Sachs, 1998, "The Onset of the East Asian Financial Crisis", NBER Working Paper No. 6680 (Cambridge, Massachusetts: National Bureau of Economic Research).

Schneider, M. and A. Tornell, 2001 "Balance Sheet Effects, Bailout Guarantees, and Financial Crises”, Paper presented at the IMF Research Department Seminar, June 19, 2001.

Smith, P., 1997, "Model Misspecification in Data Envelopment Analysis," Annals of Operations Research, 73, 233-52.

Stiglitz, J. and A. Weiss, 1981, "Credit Rationing in Markets with Imperfect Information," American Economic Review, 71 (3), pp. 393-410.

Stevenson, R., 1980, "Likelihood Functions for Generalized Stochastic Frontier Estimation," Journal of Econometrics, 13, pp. 57-66.

Waldman, D., 1982, “A Stationary Point for the Stochastic Frontier Likelihood," Journal of Econometrics, 18, pp. 275-79.

World Bank ,1999, East Asia: Recovery and Beyond, Washington DC. 